\title{
NATIONALISM IN INDIA
}

\author{
Andrew Jacob
}

\begin{abstract}
This article is aimed at an analysis of the imagining of Indian Nationalism and in locating scholarship that highlights such nationalism's inability to encompass the intense cultural diversity of the country. The article reviews a) early writings on Indian Nationalism that insisted on some form of homogenising civilizational core that would promote a sense of 'Indian-ness' above group identities to b) current scholarship's understanding of Indian Nationalism as a nation of multiple histories and voices not needing any sort of homogeneity and locating firmly the Nation as a site of debate and dispute. It is at this point that a reading of B.R.Ambedkar's conception of Indian nationalism provides a unique insight into the current thinking on the imagining of the nation. Ambedkar argues that democracy can provide for a site of debate and dispute and also the much needed homogeneity or sense of belonging that is required among peoples for effective non-ascriptive nation building. The article also analyses how this version of democracy can be viewed as a progenitor of deliberative democracy formulated by Jürgen Habermas and at the same time provide for meaningful perspective on possibly solving some of the issues that Habermas' conception failed to answer.
\end{abstract}

\section{Introduction}

There is consensus among current thinkers that the nation is based on consent, on some form of collective mental construct, of 'shared memories' in common which are in a sense, magined by individuals who want to live together under a single nation. Nationalism is today widely recognized as a modern occurrence, strongly motivated by Enlightenment, Romanticism, developed in an economic environment heavily influenced by Industrial capitalism and the product of particular lineages of Europe in the eighteenth and nineteenth centuries which led to the transformation of authoritarian dynastic empires into democratic nation-states. ${ }^{1}$ The conception of the nation in Europe therefore came to be closely associated with the ideas of self-determination, states and sovereignty. Such an idea then travelled to the sub-continent through the pathways of empires. However the European model of the 'nation' had very little association with the existing ethnic, racial and religious communities in the sub-continent. It was this mismatch of the idea of the 'nation' and its 'soil' (the life world of the people) from which the processes of nation building began to emerge.

This 'mismatch' led to various problems in imagining the nation in the British Indian Empire. Firstly there were numerous languages, castes, two major religious groups, the Hindus and Muslims and a large number of minor religions. Looking at the pre-colonial history of state formation we find that unlike in Europe, sovereignty was not conceptualized as a centralized absolute power; it was always shared with the periphery. There are various historical arguments that support the above contention. During the period of the Mughal Empire the emperor shared his power with regional polities. The political structures that existed prior to the colonial era shared their power and sovereignty with lower level leaders. There was a sense of incorporation of lesser sovereigns rather than subordination. In such a political system it was very difficult to imagine firm territorial boundaries of states drawn on maps. The fixed drawing out of territorial demarcations happened only with the arrival of the colonial era. The consequence of such fluid territorial boundaries in pre-colonial India was 
that people could not think of themselves as territorially-anchored populations which could become core groups for imagining the nation. ${ }^{2}$

\section{Debates on the Nation}

Many Imperial observers had argued that India was only a geographical expression and creation of the British Empire. It was not a single nation. There were many distinct nations within, composed of distinct languages, races and castes. ${ }^{3}$

Anderson suggested that national imagining or construction in the colonies (inclusive of India) was facilitated by the colonial regime. This was done by the introduction of western forms of education and print capitalism which in turn created an intelligentsia that was essential to the process of imagining the nation. They were helped by the institution of the colonial state such as cartographers who drew the boundaries, and census departments that solidified communities by enumeration. In consequence the colonial intelligentsia chose their version of nationalism from Europe and America and applied them to their own countries with improvements to suits their specific contexts. ${ }^{4}$

However, Anderson's idea of nationalism has been debated. An influential contestation of Anderson's ideas has come from Partho Chatterjee. In his essay 'Whose Imagined community ${ }^{5}$ Chatterjee argues that the model Anderson used was too heavily based on European and Western Hemisphere examples. The colonial revolts of the nineteenth and twentieth centuries in Asia and Africa created an 'anti-colonial nationalism' that was significantly distinct from the western nations, with its enlightenment philosophies of social contract and constitution. Class and caste structures, gender relations and spiritual and historical traditions created forms of nationalism at variance with what was formed in Europe and America.

Chatterjee argues that in the case of Indian nationalism the most important problematic was that the Indian nation did not inhabit homogeneous empty time but rather the heterogeneous time of modernity. He posits that the working class of India did not internalize the ethos of capitalism and the peasants, even when they participated in nationalist events, had very different understandings of these events derived from their dissimilar life experiences. Politics therefore did not mean the same things to all people. In such a context where the vast majority of people are so unevenly influenced by modernity did education and print capitalism play the same role as envisaged by Anderson? If not what was the specific process of nationalist imagining in India? And how did this Indian concept of the nation relate to territory and the inherent pluralism of the population contained therein? ${ }^{6}$

To the question about what the specific process of imagining ${ }^{7}$ the Indian nation, Chatterjee conceptualizes a division of the nation's space into an inner spiritual space and on outer public space. The inner spiritual space is where the colonized nation seeks its sovereignty in spite of its subjection by western influences in the outer space. ${ }^{8}$ As Dipesh Chakrabarty argues the nation therefore is experienced (felt) through this inner spiritual space and not through some rational or mental process. It was through such modes of spiritual imagination that Indian nationalism could permeate across various levels of popular consciousness. ${ }^{9}$

A significant amount of study on nationalist iconography illustrates the above point. ${ }^{10}$ What is important to gather, however, is that the symbols of the nation, such as the Indian flag or Mother India or Bharat Mata - helped to provide sources or spaces where national feeling could make itself 'felt' among people. Importantly this nationalist iconography left the people of India with images of a cultural space that nationalist ideologues of the time encouraged to be seen as the elements of a unified civilization that existed prior to the British Indian Empire. The use of such symbols as evocative of a past culture or civilization were powerful tools in establishing colonial resistance. ${ }^{11}$ 
Sekhar Bandyopadhyay points out that such a broad universalizing cultural conception is spelt out more clearly in the writings of Rabindranath Tagore. In the poem Geetanjali Tagore described the Indian civilization as a meeting ground for various kinds of humanity rather than simply a territorial unit or country. In Tagore's essay 'The History of India' the idea of the 'meeting ground' is further developed. Tagore argued that despite India being subjected to invasions by various peoples - Huns, Greeks etc., many invaders settled down in India and in due course of time were themselves 'Indianized' leaving their mark on Indian art and culture further enriching Indian diversity. This inclusive civilisational community and its assimilative spirit was what true 'Indian-ness' was. This true 'Indian-ness' could not be rationally understood but had to be felt. ${ }^{12}$

Similarly, Gandhi too was developing the idea in his book Hind Swaraj. Here Gandhi, in response to the question 'Who is the Nation?' posited that it is only those Indians that conscientiously believe that Indian civilization is the best. He argued that this civilization flourished in a certain geographical space that was linguistically differentiated. In due course of time the people learnt each other's languages and visited each other's regions. This civilization was not exclusive; the introduction of foreigners did not destroy the nation but merged into it. A country is one nation only when such a condition is obtained in its history. ${ }^{13}$ Tagore, Gandhi and later Nehru ${ }^{14}$ were trying to push back the history of the Indian nation to 3000 BC when the Indus Valley Civilization flourished or to at least 1800 BC when the Rig Vedas were composed. A number of thinkers have questioned such linear and retrospective biographies of the history of the nation. Prasenjit Duara, for instance, in his book Rescuing History from the Nation offers a systematic account of the relationship between the nationstate, nationalism, and the concept of linear history. In his discussion on Indian history he argues that many thinkers writing of postcolonial nation-states had adopted a linear, evolutionary history of the Enlightenment/colonial model to justify its existence. As a result, they have written repressive, exclusionary, and incomplete accounts. He posits further that such formulations are teleological models of enlightenment history that tended to give the contested and contingent nation a false sense of history. ${ }^{15}$ However, the reasons for such models of the nation's history could also have a political motivation. Tagore, Gandhi and Nehru were trying to find in the long past of India, not a modern territorial nation but a premodern civilisational core, that would transform itself into a national identity and finally into nationhood. ${ }^{16}$

Rajat Ray in his book The Felt Community argues that this search for a longer view of history reveals the process by which civilization effected its transition to nationhood. An important watershed in this process of transition was the revolt of 1857 . The rebels constantly referred to the people of India as the Hindus and Musalmans of Hindustan. This was not some modern European concept of nationalism but the germination of the idea of an inchoate nation. It signified a confederation of two separate peoples bound together as one political unit by the shared perception of Hindustan as one land. ${ }^{17}$

The concept of the Indian nation as a confederate nation was expressed in the 1890s by Sir Syed Ahmed Khan when he visualized India as a confederate nation of 'quams' or communities based on descent, where entitlements and rights would be determined by community identity rather than the western notion of individual citizenship. Even Sir Muhammad Iqbal in 1930 argued that the units of Indian society are not territorial as in European countries. The principle of European democracy could not be applied to Indian without recognizing the fact of communal groups. The Muslim demand for the creation of Muslim India is therefore perfectly justified. ${ }^{18}$ Important to note is that Iqbal at the time was not demanding a separate sovereign nation-state for the Muslims but recognition of a confederate nation. Gandhi too believed in this idea when he gave leadership to the Noncooperation Khilafat movement of 1920. However Gandhi seemed to have changed his 
position when he declared that 'we are Indians first and Hindus, Musalmans, Parsis and Christians after'. ${ }^{19}$ Bandyopadhyay argues that 'Indian-ness' thus does not co-exist with but takes precedence over all other identities. ${ }^{20}$ By 1922 the Indian National Congress embraced the Western concept of Nationhood based on individual citizenship. The ultimate goal of this nationalism was to achieve sovereignty for the Indian nation-state. It was expected that the nation would speak in one voice and would provide legitimacy to the nation-State. This inclusive sentiment however was fraught with difficulties as other heterogeneous voices were now delegitimized.

In other words, as mentioned earlier, the imagining of the nation became fixed in a quest to purify and control both land and people. Such an imagining would be dangerous as it did not take into account the very real diversity that did exist in India. As the history of Indian nationalism suggests, it was difficult to muffle all the discordant voices, which questioned the official nationalism of the Congress - like the Muslim breakaway politics after 1937 leading up to the partition and subsequent violence- as well as the powerful critical voices of the untouchables, significant anti-Brahmin movements and the regional-linguistic politics of South India.

\section{Cultural Memory}

This leads us back to the problem that in a country where people spoke in so many languages, where the caste system exercised a heavy influence on the stratification of groups of people, where religion played a (sometimes) divisive role, the Renan like 'shared memories' of the past critical to the imagining of a nation would reflect the existent inequality. ${ }^{21}$ The Collective conscience that was meant to be the building blocks of the Indian nation was developed from a selective cultural memory of some form of Indian civilisational core that was at instances not in concomitance with the actual diversity and history of India. ${ }^{22}$ The identification/selection of what is part of the national story, the shared memories of the people, occurred at the level of ideas and consciousness but this consciousness or sentiment had then to be situated, and was often reflected in terms of the social forms and practices in which it was embodied in the first place.

B.R. Ambedkar, was aware of the above problem. For him the homogenizing civilisational core of India that leaders like Tagore, Gandhi and Nehru tried to create in the hope of finding some form of 'fundamental true essence' or 'Indian-ness' was not reflective of the actualities of Indian society, that is, its socio-political-cultural practices or its history. ${ }^{23}$ Further in translating this lopsided view of 'Indian-ness' into a national identity that would lead to the formation of a unified Indian nation-state, the Indian nation-state itself would merely reflect the stratification existent within Indian society and benefit only those groups/ individuals at the more powerful dominant end of the stratification.

Ambedkar, in effect, was one of the first thinkers to question the very inclusive nature of Indian Civilization and the nationalism that would be derived from it. In the essay Annihilation of Caste $^{24}$ Ambedkar perceived that the foundational principle of Indian civilization was caste exclusion or the Varnashrama Dharma, which condemned a large portion of the Indian population to the status of social outsiders in their own land. Both Tagore and Gandhi accepted that untouchability was a blot on Indian civilization and needed eradication but they considered it a distortion or aberration rather than a foundational principle of Indian civilization. ${ }^{25}$ Ambedkar however rejected the reformist solutions put forward, branding it as a deliberate attempt to obfuscate the real issue of empowering the Dalit. In the early 1940's Ambedkar wrote two major books criticizing the way untouchables and minorities ${ }^{26}$ were being treated. ${ }^{27}$ He was worried about the share of freedom that these minorities would receive in the eventuality of a Free India. ${ }^{28}$ Ambedkar argued that the untouchables are not opposed to freedom from British Imperialism, but they refused to be 
content with mere freedom from British imperialism. What the untouchables insisted on is that a free India is not enough. Free India should be made safe for democracy. Starting with this aim the untouchables argue that due to the peculiar social formation in India there are minority communities pitted against a Hindu communal majority, that if no provisions are made in the constitution against the domination of such a majority, India will not be safe for democracy. ${ }^{29}$ Ambedkar was not opposed to Swaraj but wanted political, educational, economic and social safeguards for untouchables and minorities. He wanted a recognition and respect for the different voices and cultures of minority communities within the nation space. Ambedkar, further analyzed the reasons why such safeguards were being objected to by the Hindu elites and laid the blame on Gandhi and Congress leaders and the narrow chauvinistic outlook they had due to their exclusivist Brahmanical backgrounds and their methods of trying to locate the validity of the Indian nation in some form of 'universal Indian civilisational core'. Ambedkar then suggested in Mr. Gandhi and the Emancipation of the Untouchables that after all there was no nation of Indians in the real sense of the term. He posited that that the nation does not exist, it is to be created, and it was needed to be admitted that the suppression of distinct and separate communities was not the method of creating a nation. ${ }^{30}$ In his book Pakistan or the Partition of India, Ambedkar provides for a different approach to the idea of 'creating' a nation which did not take into account the deterministic elements of a homogenizing civilisational core or a supposed 'pre-given' commonly shared culture. $^{31}$

Recently, Aditya Nigam has argued in his book The Insurrection of Little Selves: The Crisis of Secular-Nationalism in India that the whole project of Indian nationhood was and is an impossible project. He argues that for nations to become true nations there is a requirement that a common homogeneous cultural identity to exist. ${ }^{32}$ However, little homogeneity actually exists. G. Aloysius, in consequence has argued about Nationalism Without a Nation. ${ }^{33}$ On the other hand there has been the argument and recognition that the Indian state must be defined as a 'Multi-national' state. ${ }^{34}$ The interesting thing to note though is that both these positions assume that a nation has to be homogenous and it has to speak in a single voice otherwise the Indian nation is not a nation. There is though, recognition that Indian nationalism is not homogeneous but plural. However, once again the assumption underlying the concept of plurality is that there is some form of unity, a unity in diversity, an idea of India. This unity that lies beneath the plurality of the Indian nation is the common democratic experience shared by all the diverse sections of India society. ${ }^{35}$ However, democracy functions at many levels in the political life of a nation, one may be at the 'pedagogic level' of the educated elites and the other at the 'performative level' of the masses. ${ }^{36}$ Recently India has been described as an unnatural nation because it does not fit into any available political models that derived from the experience of European history. ${ }^{37}$ However, India is a nation nonetheless.

In consequence a current understanding of the Indian nation is that one need not expect it to speak in one voice; neither does it need some form of homogenised identity that provides legitimacy to the state. With the above two expectations removed, the nation may be recognised as composed of multiple voices. The recognition of these different voices does not endanger the state, since discussing the fragments is not advocating the fragmentation of India. Not all the fragments demand sovereignty; rather, many seek recognition within the broader nation-space. Instead of searching for homogeneity or some form of underlying unity one should consider the nation as a site of debate and dispute between competing imaginings of different ideological and political interests. It is at this juncture of the understanding of the nation that Ambedkar's intervention is both interesting and innovative. As opposed to the above understanding of the nation, Ambedkar called for a conceptualising of the Indian nation both as a site of dispute and debate and at the same time afford for a sense of homogeneity and unity in a deeply diverse country like India. 
As shown, Ambedkar's vision of nationalism was closely linked to the idea that a nation is to be created. For him, nationalism was a project that required the development and encouragement of a sense of common belonging among the diverse people of India. In a sense, a more representative and inclusive nationalism was directly proportional to the level of 'common belonging' ${ }^{38}$ the people of India shared with one another.

To achieve this will or sentiment for diverse people to live together as a single nation, Ambedkar used and built upon a large and varied body of ideas. Around the period of his writing on the ideas of nationalism, it had generally come to be accepted in many circles, both in India and abroad, that a sovereign people, in order to have a sense of common belonging or unity, needed already to have an antecedent unity or culture, history or language. So, behind the nation there had to be a pre-existing cultural (sometimes ethnic) nation.

Ambedkar, however, recognised the ascriptive dangers of such a form of unity. He found that if culture was to be the determining basis of common belonging or identity, the caste system would have a negative effect on any sense of unity among the people of India. Ambedkar, therefore, felt that the caste system itself would require to be eradicated. To do this, he advocated that any culture of the past, if it were to be used as the base or medium of common belonging, be tested such that it would make for a better society. What was this better society for Ambedkar?

For Ambedkar, such a society was one where there was a high degree of social mobility among diverse groups and individuals; in other words, an ideal society required a high degree of social endosmosis. This simply meant that individuals could have varied, yet equally free points of contact to share and deliberate upon their interests and goals. These shared experiences, Ambedkar felt, was the key requirement towards the encouragement of a sentiment of common belonging, a sense of fraternity. Consequently, anything that hindered social endosmosis was considered to be a negative feature for society and must be eliminated. Therefore, a hierarchically arranged social grouping such as the caste system which prevented the free movement of people and ideas, and thus inhibiting social endosmosis, needed to be removed.

This sense of common belonging or fraternity for Ambedkar was just another name for democracy. He argued that democracy was not just a form of government but was primarily a mode of associated living of conjoint communicated experience. Democracy, therefore, was critical to the formation of common belonging which in turn was central to the formation of an inclusive and representative nationalism.

But this form of associated living could not exist merely at the political level. It was first of all to be present at the social level. Social democracy, for Ambedkar, became an important ingredient to the achievement of any sense of common belonging. This explains his lukewarm response to the call of Swaraj for India. He felt that the social order of society was still stratified, unjust and anti-democratic, and believed that the Indian nation would be representative of the 'haves' of Indian society. The majority of 'have-nots' would have no place in the new Indian Nation. He was questioning the inclusive nature of the Indian nation. In consequence, he demanded a significant amount of social, economic, political and educational safeguards for the perceived have-nots. However, he pushed further. He did believe in the integration of Indian society into a 'whole'. What were the methods by which such integration could be achieved?

It must be remembered that Ambedkar was a thinker who cared a great deal for reason and critical inquiry. He felt that the nation was indeed a place for rational dispute and debate. In accordance to the above, I argue that, he prescribed for 'common cycles of participation' between diverse communities. Such participation would enhance the feeling of common belonging between different peoples. How was this possible? Ambedkar argued that common cycles of participation essentially meant that people would come together and deliberate upon 
their interests towards commonly achievable goals. Such a process would naturally foster a sense of trust between diverse groups and promote a sentiment or will for people to live together. This was an important factor in the formation of a nation.

The common cycles of participation could exist (and be strengthened) if there was the presence of democratic institutions, such as a constitution, parliament, rights, the rule of law, etc. However, Ambedkar was aware that institutions and laws were not effective if people themselves were determined to be against it. He needed a process by which the people would be able to listen to the value of democratic institutions and contribute to them effectively. In a sense, political reforms were not enough. What was needed were social reforms to radically change the 'nature' of India society from one of hierarchy and privileges based on religion, to one that was just and democratic and based on the respect of fellow men, reason and critical inquiry. Ambedkar's social reforms were in consequence directed quite simply to the 'levelling out' of Indian society and he spent a significant amount of his professional career towards the realization of this vision.

Ambedkar's social reforms were significantly voluminous and an enumeration of them would be outside the ambit of this conclusion. However, we can notice that his social reforms geared at redrawing the social plane of India from one that was stratified to one that was level can be grouped into two clusters. The first cluster included reforms geared to develop and enhance the social mobility of individuals in society. Their aim being to create different points of contact in society wherein people were able to share and communicate their experiences and goals (conjoint-communicated experience). Such a process would lead to the creation of a social endosmosis and an associated life in society. The second cluster of reforms was directed at the social conscience of Indian society. Ambedkar aimed here to institute a moral foundation, a kind of social ethic which was akin to Dhamma that would emphasise that men were self-defining moral agencies; men were to be treated with respect and institute the values of liberty, equality and fraternity that could guide the morality of Individuals.

These two clusters of reforms, taken together, would enhance the democratic character of society as well as strengthen the political institutions that lie above it, effectively opening up spaces for common cycles of participation between diverse individuals and groups. Further, the moral foundation which Ambedkar sought to institute would by its very nature inform the rules of deliberation between individual and groups, and at the same time, be redrawn by the individuals and groups who are part of such deliberation since the rules themselves are open to rational and critical inquiry. For Ambedkar therefore, a democracy was not just based on the concept of the equality of citizenship but also rooted in a sensitivity to the other. His vision of democracy would provide for the conduits through which the other is allowed to penetrate the life world of the self and vice versa. Such a democratic atmosphere would enhance the sense of common belonging between diverse peoples providing for an inclusive nation.

Ambedkar's view on democracy and its linkage to the idea of an inclusive nationalism can be viewed as a progenitor of Jürgen Habermas's conception of deliberative democracy and its linkage to civic nationalism.

\section{Habermas's Deliberative Democracy}

Habermas sees human beings as constituted by a network of social relationships that opens up a public space. The fundamental intersubjectivity of the human constitution in turn implies a community or a medium of linguistic communication. Communication, for Habermas, consists in trying to agree with one another on a fact or an event in the world. In his theoretical framework, communicative action, and more specifically discussion consists of an exchange of reasons that assess the validity claims implicitly or explicitly put forward by an interlocutor. Morality, for instance, as it is understood in discourse ethics, assesses the validity 
of actions and judgements based on their possible approval from all those concerned within a practical discussion satisfying conditions of liberty and equality. ${ }^{39}$ As for the question of truth, what Habermas focuses on is the pragmatic and intersubjective dimension of truth assertions. ${ }^{40}$ This is not to say that he does not posit an objective reality beyond any subjective and intersubjective consideration, but that he conceives truth primarily as a claim raised against one or many interlocutors who must take a stand, affirmatively or negatively.

Therefore in the field of politics, Habermas has taken a special interest in the specifically political public sphere of the democratic community, in so far as this public sphere plays a central role in the integration of citizens. The process of public opinion and popular will formation generated within the public sphere constitutes the collective cement uniting individuals who, for the most part, will never meet. Moreover, it serves a locus of collective reflectivity from which laws emanate. Citizens are thereby able to perceive themselves both as the addresser and the addressee of these laws.

Therefore in Habermas's theory of democracy, the true functional requirements for democratic will formation rest on the communicative circuits of a political public sphere. ${ }^{41}$ In a sense Ambedkar's vision of true democratic will formation could exists only by removing the fetters to social mobility to enhance public deliberation (common cycles of participation) and create a conjoint-communicative experience (an associated life) among individuals. In consequence democracy is defined primarily by will formation among the people which in turn would influence the governing bodies, including the idea of the nation through diverse modes of pressure. To use the language of Rawls, the definitive idea of such deliberative democracy is the idea of deliberation itself. ${ }^{42}$ When individuals deliberate, they exchange views and debate their supporting reasons concerning public political questions. To push the idea a little further, such an exchange and debate of interests between individuals can be expected to generate a feeling of fellowship/fraternity crucial in the formation of a nation.

According to Habermas, there is no need in this deliberative model for a concept of nation that would provide a prior consensus among a homogeneous group of citizens, 'a prior background consensus based on a homogeneous culture is not necessary, because democratically structured opinion and will formation make possible rational agreement even between strangers. ${ }^{43}$ One could thereby, as Habermas thinks, escape the logic of exclusion peculiar to nations, in that all self-legislating citizens are equally included. Important to mention here is that Habermas specifically challenges the idea of the Volksnation, or ethnic nation, and that he implicitly defends the idea of a civic nation founded, as is right and proper, on the principles of justice. Given that the civic nation is understood as the integration of citizens by way of public discussion according to democratic procedures and the rule of law. Habermas asks: "how are we to define the totality of those to whom citizen's rights should legitimately apply?" 44 To put the question by Habermas a little differently, how are democratic state borders to be set? For ethno-nationalists, this question is not at all problematic since they can refer to the ethnic nation as a pre-political criterion of inclusion and exclusion. But in a democratic system based solely on holders of individual rights, on citizens self-legislating in a necessarily inclusive public sphere, the question becomes a little more difficult to answer. Habermas is critical of a type of nationalism that one can define as 'statist', i.e., nationalism that seeks to have the borders of a nation coincide with those of the state. His critique takes up the arguments that are well known since Elie Kedourie, that is, those pertaining above all to the ill-fated consequences of this type of nationalism: ensuing conflicts, the creation of new minorities, the repressive violence related to the homogenisation of a territory, etc. ${ }^{45}$ However Habermas is unable to answer his own question regarding the borders of a constitutional state. He merely insists on minority rights and, when they are respected, on the illegitimacy of separatism. 


\section{Conclusion}

In conclusion perhaps Ambedkar conception of Nationalism and Democracy may be of use here. For him, as has been argued, the idea of a nation based on some core cultural past had significant ascriptive dangers. However, he felt that culture itself could be tested through the criterion of reason, secularity and respect for human agency. He felt that democratic deliberation itself, infused with the principles of Dhamma (i.e., the principles of justiceliberty, equality and fraternity) would help individuals pick and choose only those aspects of culture that upheld the principles of justice. Such a 'retrieved' culture would help create a significant impetus to the feeling of common belonging among individuals further bolstering and encouraging the deliberative atmosphere of society. A deliberative democracy grounded in such a 'retrieved culture' perhaps may help individuals imagine the limits as well as the possibilities of the physical as well as mental borders of a nation. This process may then avoid the inherent violence that exists in the construction of a nation that both Kedourie and Habermas had warned of.

\section{Notes}

${ }^{1}$ See, Sekhar Bandyopadhyay (ed.), Nationalist Movement in India: A Reader, New Delhi: Oxford University Press, 2009, p. xvi.

${ }^{2}$ Ibid., p. xvii.

${ }^{3}$ See Rajat K. Ray, “The Interpretation of Indian Nationalism”, in B.R. Nanda (ed.), Essays in Modern Indian History, New Delhi, Oxford University Press, 1980, p. 37.

${ }^{4}$ Benedict Anderson, Imagined Communities: Reflections on the Origin and Spread of Nationalism, London: Verso, $2^{\text {nd }}$ Edition, 2006, pp. 113-140.

${ }^{5}$ Partho Chatterjee, "Whose Imagined Community”, in Gopal Balakrishnan (ed.), Mapping the Nation, London: Verso, 1996, pp. 214-225.

${ }^{6}$ See, Sekhar Bandyopadhyay (ed.), Nationalist Movement in India: A Reader, New Delhi: Oxford University Press, 2009, pp. viii-xix.

${ }^{7}$ Imagining as different from Anderson's modernist rational process.

${ }^{8}$ See, Partha Chattejee, The Nation and its Fragments: Colonial and Postcolonial Histories, Princeton: Princeton University Press, 1993.

${ }^{9}$ Dipesh Chakrabarty, Provincialising Europe: Post-Colonial Thought and Historical Difference, Princeton and Oxford: Princeton University Press, 2000, pp. 172-179.

${ }^{10}$ The spiritual imagination of the Indian nation can be seen for instance, in the origin, evolution, meaning and tropes that surrounded the images of 'Mother India', for instance see, Erwin Neumayer and Christine Schelberger, Bharat Mata: India's Freedom Movements in Popular Art, New Delhi: Oxford University Press, 2007 and Christopher Pinney, "'A Secret of their own country”: Or, how Indian Nationalism made itself irrefutable', in S. Ramaswamy, (ed.), Beyond Appearances? Visual Practices and Ideologies in Modern India, New Delhi: Thousand Oaks, London, Sage Publications, 2003. For the origin, evolution and meaning that surrounded the 'National Flag', see, Arundhati Virmani, "Nationalism Symbols under Colonial Domination: The Nationalization of the Indian Flag, March-August 1923”, Past and Present, 164, August, 1999, pp. 171, 178, 180. Also see, Sekhar Bandyopadhyay (ed), Nationalist Movement in India: A Reader, New Delhi: Oxford University Press, 2009, pp-xix-xx.

${ }^{11}$ Sunil Khilnani, The Idea of India, New Delhi: Penguin, Reprinted with a new Introduction, 2004, p. 155

${ }^{12}$ See, Sekhar Bandyopadhyay (ed.), Nationalist Movement in India: A Reader, New Delhi: Oxford University Press, 2009, pp. xxi-xxii.

${ }^{13}$ See, M.K. Gandhi, Hind Swaraj and Other Writings, (ed.) Anthony J. Parel, Cambridge: Cambridge University Press, 1997, pp. 52, 115-116. 
${ }^{14}$ Jawaharlal Nehru, Discovery of India, New Delhi: Jawaharlal Nehru Memorial Fund/ Oxford University Press, 2002.

${ }^{15}$ See, Prasenjit Duara, Rescuing History from the Nation: Questioning Narratives of Modern China, Chicago and London: University of Chicago Press, 1995, p. 4.

${ }^{16}$ See C. A. Bayly, Origins of Natinality in South Asia: Patriotism and Ethical Government in the Making of Modern India, New Delhi: Oxford University Press 1998. Also see, Irfan Habib (ed.), India-Studies in the History of an Idea, New Delhi: Munshiram Manorharlal, 2004.

17 See Rajat Ray, The Felt Community: Commonality and Mentality before the Emergence of Indian Nationalism, New Delhi: Oxford University Press, 2003, pp., 537, 543, 545, cited in Sekhar Bandyopadhyay (ed), Nationalist Movement in India: A Reader, New Delhi: Oxford University Press, 2009, p. xxii-xxiv.

${ }^{18}$ Sekhar Bandyopadhyay (ed.), Nationalist Movement in India: A Reader, New Delhi: Oxford University Press, 2009, p. xxiv.

${ }^{19}$ Gyanendra Pandey, The Construction of Communalism in Colonial North India, New Delhi: Oxford University Press, $2^{\text {nd }}$ Edition, 2006, p. 210 ad passim, in, The Gyanendra Pandey Omnibus, New Delhi: Oxford University Press, 2008.

${ }^{20}$ Sekhar Bandyopadhyay, (ed.), Nationalist Movement in India: A Reader, New Delhi: Oxford University Press, 2009, p. xxiv.

${ }^{21}$ See, Kudi Arasu, 19 March 1933 in, Periyar E.V. Ramasami, Words of Freedom: Ideas of A Nation: Periayar E.V. Ramasami, (trs), V.Geetha and S.V. Rajadurai, New Delhi: Penguin Books, 2010, pp. 39-40.

${ }^{22}$ See, Gyanendra Pandey, Routine Violence: Nations, Fragments, Histories, California: Stanford University Press, 2006, pp. 103-128. Also see, Prasenjit Duara, Rescuing History from the Nation: Questioning Narratives of Modern China, Chicago and London: Chicago University Press, 1995.

${ }^{23}$ Shahid Amin, Event, Metaphor, Memory: Chauri Chaura 1922-92, New Delhi: Oxford University Press, 1996. D.E.U. Baker, Baghelkhand, or the Tigers Lair Region and the Nation in Indian History, New Delhi: Oxford University Press, 2007 and Gyanesh Kudaisya, Region, Nation and 'Heartland': Uttar Pradesh in India's Body Politic, New Delhi and London: Thousand Oaks, Sage Publications, 2006. See, Jawaharlal Nehru, The Discovery of India, New Delhi: Jawaharlal Nehru Memorial Fund/ Oxford University Press, 2002, p. 60. see, Aditya Nigam, The Insurrection of Little Selves: The Crisis of Secular Nationalism in India, New Delhi: Oxford University Press, 2006, pp. 65-76, 222-300.

${ }^{24}$ B.R. Ambedkar, Annihilation of Caste with a Reply to Mahatma Gandhi, in Vasant Moon (ed.), Dr. Babasaheb Ambedkar's Writings and Speeches, Vol. 1, Mumbai: Government of Maharashtra, 1989, pp. 23-96.

${ }^{25}$ See, Bhikhu Parekh, Colonialism, Tradition and reform: An Analysis of Gandhi's Political Discourse, New Delhi, Newbury Park, London: Sage Publications, 1989. For a discussion on Tagore's ideas of caste see, Sekhar Bandyopadhyay, Caste, Politics and the Raj: Bengal 1872-1937, Calcutta: K.P. Bagchi and Co., 1990.

${ }^{26}$ See, B.R. Ambedkar, "What Congress and Gandhi Have Done to the Untouchables", in Vasant Moon, (ed.), Dr. Babasaheb Ambedkar's Writings and Speeches, Vol. 9, Mumbai: Government of Maharashtra, 1990, pp. ivv.

${ }^{27}$ B.R. Ambedkar, "What Congress and Gandhi have done to the Untouchables", and "Mr Gandhi and the Emancipation of the Untouchables", in Vasant Moon (ed.), Dr. Babasaheb Ambedkar's Writings and Speeches, Vol. 9, Mumbai: Government of Maharashtra, 1990.

${ }^{28}$ See, Periyar E.V. Ramasami, Words of Freedom: Ideas of A Nation: Periyar E.V. Ramasami, (trs) , V. Geetha and S.V. Rajadurai, New Delhi: Penguin Books, 2010, pp. 4-6.

${ }^{29}$ B.R. Ambedkar, What Congress and Gandhi have done to the Untouchables, in Vasant Moon, (ed.), Dr. Babasaheb Ambedkar's Writings and Speeches, Vol. 9, Mumbai: Government of Maharashtra, 1991, p. 166169.

${ }^{30}$ B.R. Ambedkar, Mr Gandhi and the Emancipation of the Untouchables, in Vasant Moon, (ed.), Dr. Babasaheb Ambedkar's Writings and Speeches, Vol. 9, Mumbai: Government of Maharashtra, 1991, p. 412.

${ }^{31}$ B.R. Ambedkar, "Pakistan or The Partition of India", in Vasant Moon (ed.), Dr. Babasaheb Ambedkar Writings and Speeches, Vol. 8, Mumbai: Government of Maharashtra, 2010.

${ }^{32}$ Aditya Nigam, The Insurrection of Little Selves: The Crisis of Secular Nationalism in India, New Delhi: Oxford University Press, 2006, p. 16. 
${ }^{33}$ G. Aloysius, Nationalism Without a Nation in India, New Delhi: Oxford University Press, 1997.

${ }^{34}$ S.L. Sharma and T.K. Oommen (eds), Nation and National Identity in South Asia, New Delhi: Orient Longman, 2000.

${ }^{35}$ See, Sunil Khilnani, The Idea of India, New Delhi: Penguin, Reprinted with a new Introduction 2004.

${ }^{36}$ See, Homi K. Bhabha, "Dissemi Nation: time, narrative, and the margins of the modern nation", in Homi K. Bhaba (ed), Nation and Narration, London and New York: Routledge, 2010 Reprint, pp. 291-320.

${ }^{37}$ Ramachandra Guha, India After Gandhi: The history of the World's Largest Democracy, New Delhi: Picador India, 2008, pp. 744-757, 771.

${ }^{38}$ The idea of 'Common Belonging' here is understood to be the will of people to want to live together under single nation.

${ }^{39}$ See, Jürgen Habermas, Moral Consciousness and Communicative Action, Cambridge, MA: MIT Press, 1990 and, Justification and Application, Cambridge, MA: MIT Press, 1993.

${ }^{40}$ Jürgen Habermas, Truth and Justification, Cambridge, MA: MIT Press, 2003.

${ }^{41}$ Jürgen Habermas, 'On the relation between the nation, the rule of law and democracy', in, C. Cronin and P. DeGreiff (eds.), The Inclusion of the Other, Cambridge, MA: MIT Press, 1998, p. 153.

${ }^{42}$ John Rawls, Collected Papers, Cambridge, M.A: Harvard University Press, 1962, pp. 579. Citied in, Amartya Sen, The Idea of Justice, New Delhi: Penguin Books, 2010, p. 324.

${ }^{43}$ Jürgen Habermas, 'On the relation between the nation, the rule of law and democracy', in, C. Cronin and P. DeGreiff (eds.), The Inclusion of the Other, Cambridge, MA: MIT Press, 1998, pp. 137-8.

${ }^{44}$ Ibid., p. 140.

${ }^{45}$ See, Elie Kedourie, Nationalism, Malden, Massachusetts: Wiley-Blackwell, $4^{\text {th }}$ Expanded Edition, 1993. 